Cite this: Indo. Chim. Acta., 2020, 13, 1.

Received Date: 4th May 2020 Accepted Date: 21st June 2020

Keywords:

food security;

soil quality;

soil contamination;

cadmium

DOI:

http://dx.doi.org/10.20956/ica.v1 $3 i 1.9751$

\section{Source of Cadmium (Cd) in Soils and Its Transfer to Rice and Vegetables: Karotia Union, Tangail}

\author{
Shamim Al Mamun ${ }^{*}$, Reyad Hossain Arif ${ }^{1}$, Md. Ariful Islam¹, Md. Sirajul Islam ${ }^{1}$, Zakia \\ Parveen ${ }^{2}$ and Muliadi $^{3}$
}

\begin{abstract}
Cadmium is a trace element which is not essential for human being. High cadmium concentration in some rice samples in Bangladesh was reported than that other countries. This study was carried out to find out the $\mathrm{Cd}$ concentration fertilizers, soils, rice and vegetables and along with other chemical properties of Karotia union, Tangail sadar upazila, Tangail. A total of 29 samples were collected among the 14 soils from 7 stations at $0-15 \mathrm{~cm}$ and $16-30 \mathrm{~cm}$ depth respectively, 5 vegetables, 5 rice and also 4 different countries TSP fertilizers from local market. The Cd concentration values of all soil samples were found between 0.97 to $1.73 \mathrm{mg} / \mathrm{kg}(0-15 \mathrm{~cm})$ and 0.53 to $0.83 \mathrm{mg} / \mathrm{kg}(16-30 \mathrm{~cm})$, respectively and the vegetable sample values were found between $0.053 \mathrm{mg} / \mathrm{kg}$ to $0.123 \mathrm{mg} / \mathrm{kg}$ (d.w.). The rice sample values were found between $0.05 \mathrm{mg} / \mathrm{kg}$ to $0.096 \mathrm{mg} / \mathrm{kg}$ (d.w.). The fertilizer sample values were found between 20.67 to $92.33 \mathrm{mg} / \mathrm{kg}$. The soil $\mathrm{pH}$ values obtained 7.06 to $7.70(0-15 \mathrm{~cm})$ and 7.48 to $7.88(16-30 \mathrm{~cm})$ which indicated that the study area soils were neutral to moderately alkaline. The EC values of all soil samples were between 47.67 to $82.67 \mathrm{dSm}-1(0-15 \mathrm{~cm})$ and 33.33 to $58.33 \mathrm{dSm}-1(16-30 \mathrm{~cm})$. The organic matter content of all soils ranged from 0.789 to $0.905 \%$ and 0.351 to $0.869 \%$ at $(0-15 \mathrm{~cm}$ and $16-30 \mathrm{~cm})$, respectively. The available sodium $(\mathrm{Na})$ values of soils were found between 1.84 to $1.92 \mathrm{ppm}(0-15 \mathrm{~cm})$ and 1.83 to $1.90 \mathrm{ppm}(16-30 \mathrm{~cm})$, respectively. The available potassium values ranged from 1.81 to $1.96 \mathrm{ppm}(0-15 \mathrm{~cm})$ and 1.84 to 1.97 ppm $(16-30 \mathrm{~cm})$, respectively. The available calcium values of all soil samples were 1.92 to $1.97 \mathrm{ppm}(0-15 \mathrm{~cm})$ and 1.91 to $1.96 \mathrm{ppm}(16-30 \mathrm{~cm})$, respectively.
\end{abstract}

\section{Introduction}

With the rapid progression of industry and increasing release of agrochemicals into the environment, the potential accumulation of heavy metals in agricultural soils has caused a growing public concern in worldwide about food security (Wong et al., 2002).The agricultural areas soil often serve as the major sink for heavy metals and that may release into the environment from different anthropogenic sources (Alloway, 1999).

${ }^{1}$ Department of Environmental Science and Resource Management, Mawlana Bhashani Science and Technology University, Tangail-1902, Bangladesh: shamim084du@gmail.com

${ }^{2}$ Department of Soil, Water and Environment, University of Dhaka, Dhaka-1000, Bangladesh.

${ }^{3}$ Department of Chemistry, Universitas Khairun, Ternate, Maluku Utara, Indonesia
Trace elements can be mobilized from arid soils through plant uptake and leaching processes, but these soils usually contain higher amounts of trace elements than other soils (Kabata-Pendias and Pendias, 2010). The contamination of soil and vegetables by heavy metals is also a global environmental issue. They are universal in the environment through various pathways, due to natural and anthropogenic activities (Wilson and Pyatt, 2007). Adulteration in fertilizers is one of the emerging problems for intensive agriculture in Bangladesh. The quality of fertilizers being sold to the farmers is often exploited by the unscrupulous elements (Mortvedt and Beaton, 1995). Phosphate fertilizers contains high concentration of cadmium (Cd) that has been reported worldwide (Kim, 2008). It is estimated that $54-58 \%$ of the $\mathrm{Cd}$ found in the environment comes from the application of mineral Jurnal Akta Kimia Indonesia, [2020], [vol.13] 16-22 | 16 
phosphate fertilizers (Tirado and Allsop, 2012). Rice (Oryza sativa L.) contains protein and is ranked as the second highly consumed cereal in the world (Rabbani et al., 2015). In Bangladesh rice contains Cd concentration much higher than the international guideline standards (Meharg et al., 2013). It is alarming that the rice intake in Bangladesh as per capita is much higher compared to the most of the countries of the worldwide. Day by day in Bangladesh, kidney patients are increasing at an alarming rate which has been linked with the $\mathrm{Cd}$ accumulation in soils. Vegetables are the important food of daily diet because they are the good source of Vitamin A and C, iron, calcium, folic acid and fiber (Garg et al., 2014). Some reports showed low birth weight and severe mental retardation of newborn children during pregnancy when the mother was exposed to toxic amounts of a heavy metal through direct or indirect consumption of vegetables (Sharma et al., 2008).Keeping all these views in mind, we aimed to analyze the cadmium concentration in soils, vegetables, rice and fertilizers at Karotia union in Tangail, Bangladesh.

\section{Experimental}

\section{Material and Methods}

Total 14 soil samples from 7 points were collected from 0 $15 \mathrm{~cm}$ (topsoil) and 15-30 cm (subsoil) depth respectively by using soil core sampler at Karotia union in Tangail, Bangladesh. Five vegetables, rice and four TSP fertilizers sample were collected from different locations at karotia union in Tangail. The collected soil and fertilizer samples were dried in an oven at $70^{\circ} \mathrm{C}$ until a constant weight is observed. After drying each sample, they were mixed thoroughly, crushed, sieved with a $2 \mathrm{~mm}$ nylon sieve and preserved in plastic pots for subsequent laboratory analysis.

The soil $\mathrm{pH}$ was measured by Digital $\mathrm{pH}$ meter (Hannah). The soil EC was measured by Digital EC meter. The total organic carbon (TOC) and percentage of organic matter $(\mathrm{OM})$ content was analyzed titrimetrically according to Walkley and Black's wet oxidation method (Walkley and Black, 1934). The available Sodium (Na) was analyzed by Ammonium acetate extraction method by using Flame Photometer $766 \mathrm{~nm}$ (Huq and Alam, 2005). The available Potassium (k) and Calcium (Ca) were analyzed by Ammonium acetate extraction method by using Flame Photometer at $589 \mathrm{~nm}$ (Huq and alam, 2005). The total Cd in soils, vegetables, rice and fertilizers were analyzed by perchloric-nitric acid digestion methods by using AAS Shimadzu 7000 (Huq and Islam, 2005).

\section{Result and Discussion}

\section{Soil pH}

The soil $\mathrm{pH}$ depends on kinds of basic rock or parent materials. The $\mathrm{pH}$ values of all soil samples were found to be ranged in between 7.06 to $7.70(0-15 \mathrm{~cm})$ and 7.48 to 7.88 (16-30 cm)which indicate that study area soils are neutral and moderate basic or alkaline. The mean values of soil $\mathrm{pH}$ were recorded 7.36 and 7.69 at the top soils and subsoils, respectively. Figure 1(a) shows the highest value of $\mathrm{pH} 7.88$ in agricultural (Tomato) land was found in the station 6 and the lowest pH value 7.06 in agricultural (Amaranths) was found in the station 1 . Hence it can be speculated that soil of this zone is neutral to moderately basic. Bhuiyan (1988) reported that the $\mathrm{pH}$ of different soil series of Bangladesh ranged from 4.4 to 8.0 due to the variation of soil ecosystem mainly.The $\mathrm{pH}$ of Tejgaon, Sonatola and Khadimnagar were 5.2, 6.5, 5.8 and 5.9, respectively (Debnath, 2002).Thus the study depicts that the $\mathrm{pH}$ range is suitable for crop production and cultivation.

\section{Soil EC}

Soil Electrical Conductivity (EC) is an important indicator of soil health that affects crop yields, crop suitability, plant nutrient availability, and activity of soil microorganisms (Smith and Doran, 1996).The EC values of all soil samples were found to be ranged in between 47.67 to $82.67 \mathrm{dSm}$ $1(0-15 \mathrm{~cm}), 33.33$ to $58.33 \mathrm{dSm}-1(16-30 \mathrm{~cm})$ which indicates that study area soils are very high electrical conductivity. The mean values of soil EC were recorded $66.57 \mathrm{dSm}-1$ and $48.80 \mathrm{dSm}-1$ at the top soils and subsoils, respectively. Figure 1(b) shows the highest value of soil EC $82.67 \mathrm{dSm}-1$ in agricultural (Amaranths) land was found in the station 1 and the lowest value of soil EC $33.33 \mathrm{dSm}-1$ in agricultural (Radish) land was found in the station 2. The electrical conductivity of the Madhupur sal forest soil ranged from 6 to $57 \mu \mathrm{S} / \mathrm{cm}$ (Gomes, 2005).

\section{Total Organic Carbon (TOC)}

Large amounts of soil organic carbon will enhance water retention, prevent leaching of soluble nutrients and maintain soil fertility (Fullen et al., 2007). The total organic carbonvalues of the samples were found to be ranged in between $0.458 \%$ to $0.525 \%$ in the agricultural soils $(0-15$ $\mathrm{cm})$ and $0.204 \%$ to $0.504 \%$ in the soils $(16-30 \mathrm{~cm})$ depth. The mean values of total organic carbon were recorded at $0.499 \%$ and $0.409 \%$ at the topsoils and subsoils, respectively. Figure 1(c) shows the highest value of TOC $0.525 \%$ in agricultural (Potato) land was found in the station 5 and the lowest value of TOC $0.204 \%$ in agricultural (Rice) land was found in the station 4 . The most agricultural soils of Bangladesh have low carbon content (Aliet al., 1997).

\section{Soil Organic Matter (SOM)}

A good soil should have at least $2.5 \%$ organic matter, but in Bangladesh, most of the soil has less than $1.5 \%$ and some 
soil possess even less than 1\% organic matter (BARC, 2005). The Soil Organic Matter values of the samples were found to be ranged in between 0.789 to $0.905 \%$ in the agricultural soils $(0-15 \mathrm{~cm})$ and 0.351 to $0.869 \%$ in the soils $(16-30 \mathrm{~cm})$. The mean values of soil organic matter were recorded at $0.860 \%$ and $0.705 \%$ at the topsoils and subsoils, respectively. Figure 1 (d) shows the highest value of SOM $0.905 \%$ in agricultural (Potato) land was found in the station 5 and the lowest value of SOM $0.351 \%$ in agricultural (Rice) land was found in the station 4. The level of SOM accumulation depends basically on tillage methods and residue management practices (Kong etal., 2009).
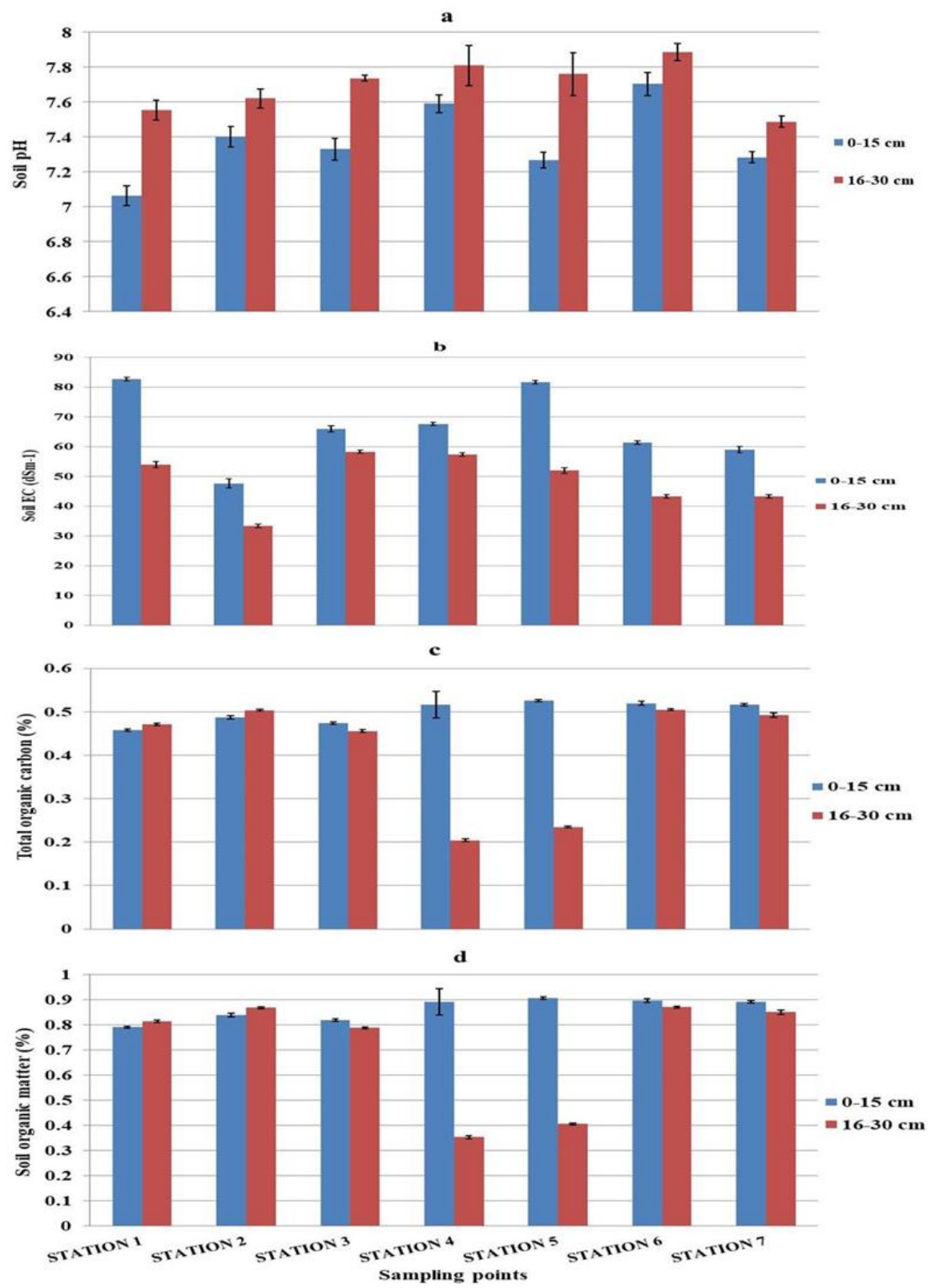

Figure 1. Status of (a) soil pH, (b) Soil EC, (c) Total Organic Carbon (TOC), and (d) Soil Organic Matter (SOM) in the study area.

\section{Available Sodium (Na)}

Sodium is an essential element for plant growth and also high levels of sodium cause plant and microbial problems and very high levels cause soil sterilization and plant damage or death (Cantisano, 1997).The available sodium $(\mathrm{Na})$ values of all soil samples were found to be ranged in between 1.84 to $1.92 \mathrm{ppm}(0-15 \mathrm{~cm})$ and 1.83 to $1.90 \mathrm{ppm}(16-30 \mathrm{~cm})$. The mean values of available sodium were recorded 1.91 and $1.92 \mathrm{ppm}$ at the top soils and subsoils, respectively. Figure 2(a) shows the highest value of available sodium 1.97 in agricultural (Spinach) land was found in the station 7 and the lowest value of available sodium 1.83 in agricultural (Rice) land was found in the station 4. The available sodium ( $\mathrm{Na}$ ) content of Chorfasion $6.25 \mathrm{meq} / 100 \mathrm{~g}$ soil and Asasuni 6.14 
meq/100g soil soils was next to Kaligonj and dominated over Dumuria $4.89 \mathrm{meq} / 100 \mathrm{~g}$ soil and Botiaghata 4.26 meq/100g soil soils (Akter et al.,2013)

\section{Available Potassium (K)}

With increasing depth, the potassium percentage usually remains about the same or increases in soils of initially uniform the parent material (Black, 1957).The available potassium $(\mathrm{K})$ values of all soil samples were found to be ranged in between 1.81 to $1.96 \mathrm{ppm}(0-15$ $\mathrm{cm})$ and 1.84 to $1.97 \mathrm{ppm}(16-30 \mathrm{~cm})$. The mean values of available potassium (K) were recorded 1.91 and 1.92 ppm at the top soils and subsoils, respectively. Figure 2(b) shows the highest value of available potassium 1.97 in agricultural (Potato) land was found in the station 5 and the lowest value of available potassium 1.81 in agricultural (Cauliflower) land was found in the station 3. The available potassium(K) content of highland, medium highland,and medium lowland under the Madhupur upazila values $0.21 \mathrm{ppm}, 0.13 \mathrm{ppm}$, and 0.16 ppm, respectively (SRDI, 2001a).The available potassium (K) level $0.20 \%$ to $1.04 \%$ represents the considering agricultural fields were fertile (Rahman et al., 2014).

\section{Available Calcium (Ca)}

Calcium is a highly mobile element in slight acid soils and it quickly leaches out of soils low in organic matter and microbial activity (Cantisano, 1997). The available calcium (Ca) values of all soil samples were found to be ranged in between 1.92 to $1.97 \mathrm{ppm}(0-15 \mathrm{~cm})$ and 1.91 to $1.96 \mathrm{ppm}(16-30 \mathrm{~cm})$. The mean values of available calcium (Ca) were recorded at 1.94 and $1.93 \mathrm{ppm}$ at the top soils and subsoils, respectively. Figure 2(c) shows the highest value of available calcium 1.97 in agricultural (Rice) land was found in the station 4 and the lowest value of available calcium 1.91 in agricultural (Amaranths) land was found in the station 1. Ideal limit of the percentage of total calcium (Ca) is four categories such as low $(<3.0)$, medium (3.1-6.0), high (6.1-7.5) and very high $(>7.5)$ (BARC, 2005).
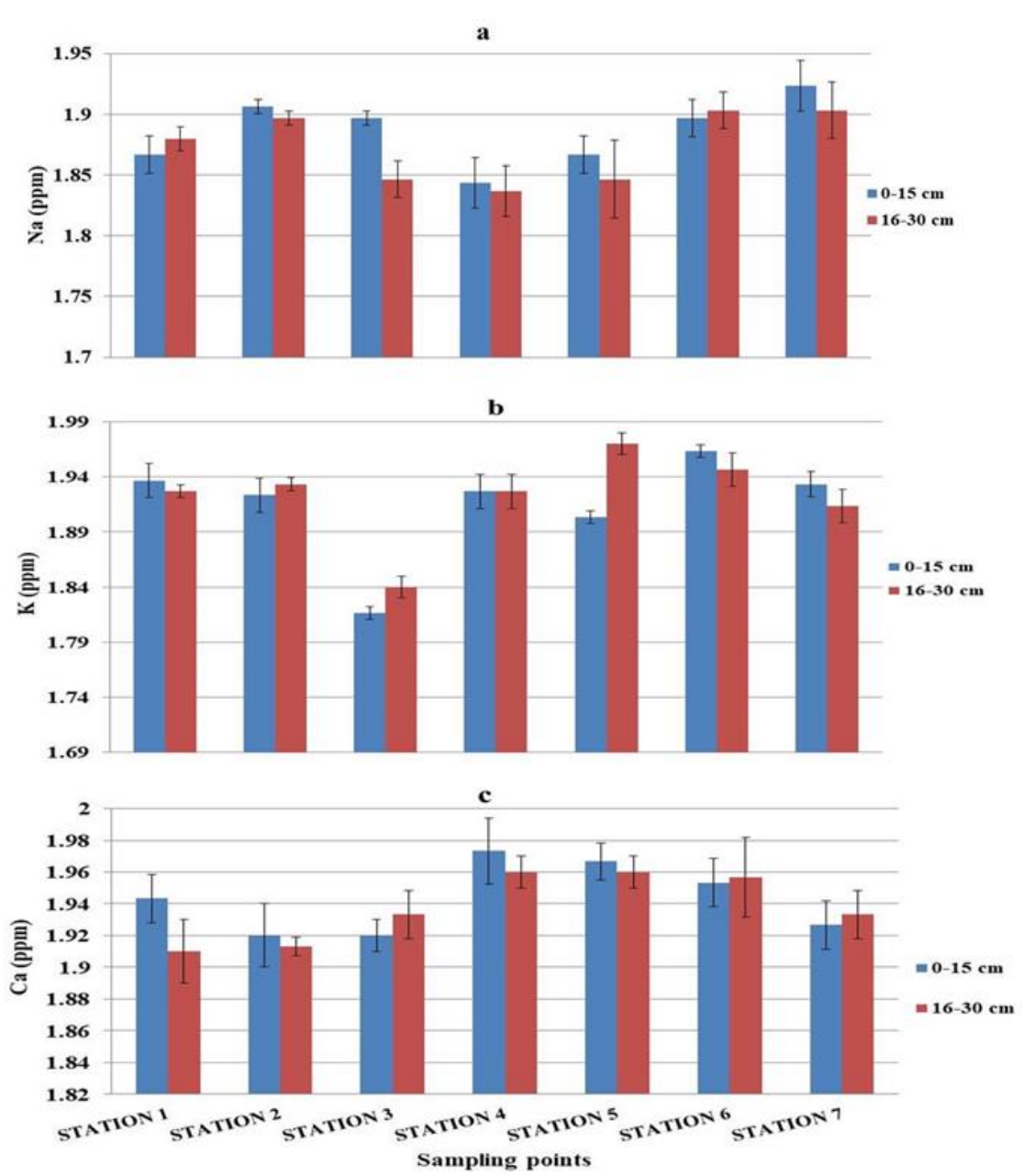

Figure 2. Status of (a) Available Sodium (Na), (b) Available Potassium (K), and (c) Available Calcium (Ca) in the study area. 


\section{Cadmium Concentration in Soil}

Trace elements can be mobilized from arid soils through plant uptake and erosion/leaching processes, but these soils usually contain higher contents of trace elements than other soils (Kabata-Pendias and Pendias, 2010).The $C d$ concentration values of all soil samples were found to be ranged in between 0.97 to $1.73 \mathrm{mg} / \mathrm{kg}$ $(0-15 \mathrm{~cm}), 0.533$ to $0.833 \mathrm{mg} / \mathrm{kg}(16-30 \mathrm{~cm})$. The mean values of $\mathrm{Cd}$ concentration were recorded 1.285 and
$0.695 \mathrm{mg} / \mathrm{kg}$ at the top soils and subsoils, respectively. Figure 3 shows the highest value of $\mathrm{Cd}(1.73 \mathrm{mg} / \mathrm{kg})$ in agricultural (Spinach) land was found in the station 7 and the lowest value of $\mathrm{Cd}(0.53 \mathrm{mg} / \mathrm{kg})$ in agricultural (Potato) land was found in the station 5. The total soil $\mathrm{Cd}$ concentration of about $0.20 \mathrm{mg} / \mathrm{kg}$ in the topsoils (0-7.5 $\mathrm{cm}$ ) of 86 non-agricultural sites in New Zealand (Roberts et al., 1994).

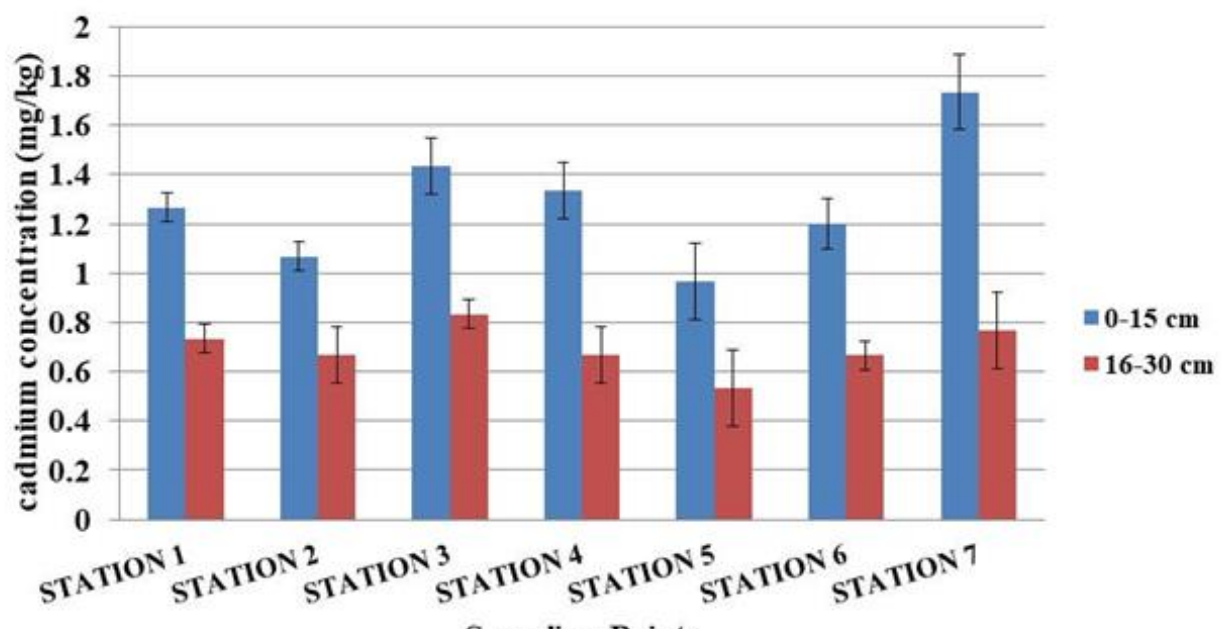

Sampling Points

Figure 3. Status of cadmium (Cd) concentration in soils at the study area.

\section{Cadmium Concentration in Vegetables}

The concentrations of trace minerals in vegetables may vary depending on the inherent and environmental conditions of plants and animals (Pennington and Calloway, 1973). The Cd concentration values of all vegetable samples were found to be ranged in between 0.053 to $0.123 \mathrm{mg} / \mathrm{kg}$. The mean values of $\mathrm{Cd}$ concentration in vegetables were recorded at $0.075 \mathrm{mg} / \mathrm{kg}$.
Figure 4 shows the highest value of $\mathrm{Cd}$ concentrations in vegetables $0.123 \mathrm{mg} / \mathrm{kg}$ in (Spinach) land which was found in the station 2 and the lowest value of $\mathrm{Cd}$ concentration in vegetables were $0.053 \mathrm{mg} / \mathrm{kg}$ in (Amaranths and Cauliflower) land which was found in the station 1. In a farmland of Tianjin, more than $60 \%$ of the vegetable samples had Cd concentrations above the standard level $0.05 \mathrm{mg} / \mathrm{kg}$ (Wang, 2012).

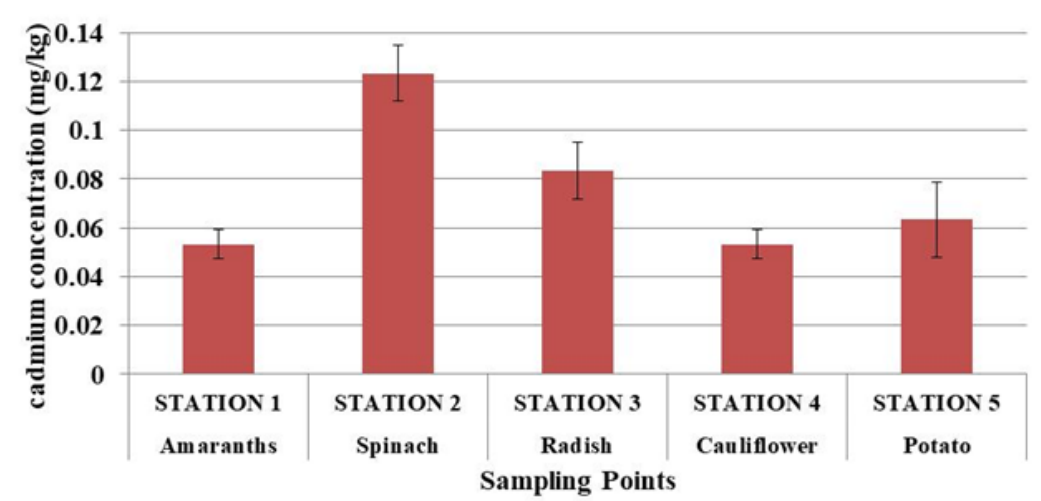

Figure 4. Status of cadmium (Cd) concentration in different vegetables at the study area. 


\section{Cadmium Concentration in Rice}

Heavy metal contamination in a rice field is an important problem directly posing a serious health risk for human beings (Cao et al., 2010). The Cd concentration values of all rice samples were found to be ranged in between 0.053 to $0.096 \mathrm{mg} / \mathrm{kg}$. The mean values of $\mathrm{Cd}$ concentration in rice were recorded at $0.065 \mathrm{mg} / \mathrm{kg}$. Figure 5 shows the highest value of $\mathrm{Cd}$ concentrations in rice $0.096 \mathrm{mg} / \mathrm{kgwhich}$ was found in the station 5 and the lowest value of $\mathrm{Cd}$ concentration in rice were $0.053 \mathrm{mg} / \mathrm{kg}$ which was found in the station 1 and 3.The Cd levels over 260 rice samples across 12 districts of Bangladesh in the range of $<0.005$ $1.31 \mathrm{mg} / \mathrm{kg}$, with the mean of $0.099 \mathrm{mg} / \mathrm{kg}$ (Meharg et al., 2013).

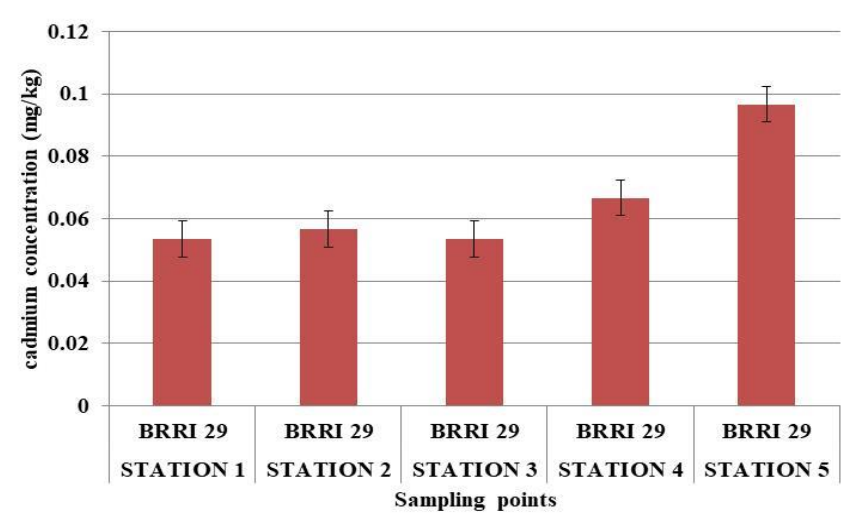

Figure 5. Status of cadmium (Cd) concentration in Paddy (Rice) at the study area

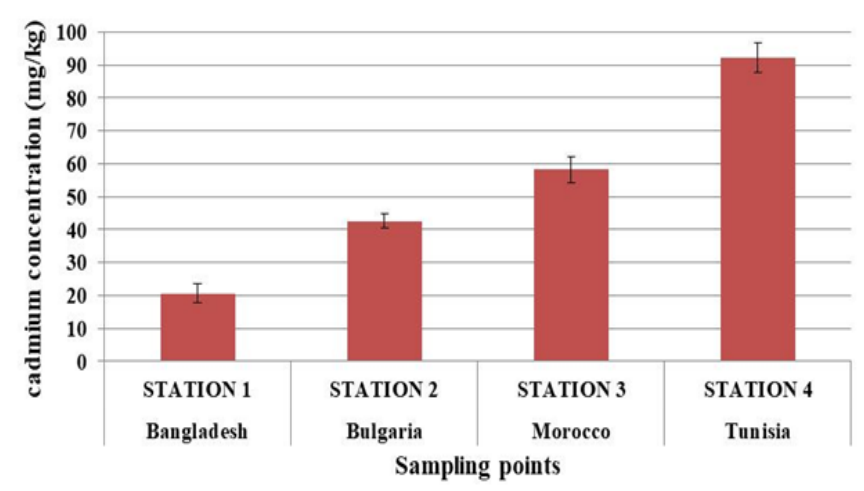

Figure 6. Status of cadmium (Cd) concentration in TSP fertilizer in the study area.

\section{Cadmium Concentration in TSP Fertilizer}

Excessive and continuous uses of phosphorous fertilizers for decades have converted the agricultural soils into virtual chemical time bombs (Dissanayake et al., 2009).The Cd concentration values of all TSP fertilizer were found to be ranged in between 20.67 to $92.33 \mathrm{mg} / \mathrm{kg}$. The mean values of $\mathrm{Cd}$ concentration in fertilizers were recorded $53.46 \mathrm{mg} / \mathrm{kg}$. Figure 6 showsthe highest value of
Cd concentrations in fertilizer $92.33 \mathrm{mg} / \mathrm{kg}$ which were imported from Tunisia and the lowest value of $\mathrm{Cd}$ concentration in fertilizer were $20.67 \mathrm{mg} / \mathrm{kg}$ which produce in Bangladesh.The $\mathrm{Cd}$ concentration in Triple Superphosphate (TSP) fertilizer was $6.74 \mathrm{mg} / \mathrm{kg}$ (Atafar et al., 2010).

\section{Conclusion}

The Cd concentration in phosphate fertilizers imported from Tunisia was found the highest among the phosphate fertilizers sold in market Tangail. Among the plant species, spinach was observed to contain high $\mathrm{Cd}$ concentration which even exceeded the permissible limits of WHO. The cadmium concentration in rice was observed $0.053 \mathrm{mg} / \mathrm{kg}$ d.w. to $0.096 \mathrm{mg} / \mathrm{kg}$ d.w. which is below the standard level of FAO/WHO. As the people in Bangladesh generally eat large amount of rice daily, thus this might cause higher daily $\mathrm{Cd}$ intake by individuals. The $\mathrm{Cd}$ concentration values of all soil samples were 0.97 to $1.73 \mathrm{mg} / \mathrm{kg}(0-15 \mathrm{~cm})$ and 0.533 to $0.833 \mathrm{mg} / \mathrm{kg}(16-30 \mathrm{~cm})$ which is above the standard level of EPA.The $\mathrm{Cd}$ concentration values of all vegetable samples were found between 0.053 to $0.123 \mathrm{mg} / \mathrm{kg}$. The $\mathrm{Cd}$ concentration values of all fertilizer samples were found 20.67 to $92.33 \mathrm{mg} / \mathrm{kg}$. If we consider a single crop in a year and consider $80 \mathrm{~kg} / \mathrm{ha}$ application rate of Phosphate fertilizer and calculate which shows that 15.70 to 70.17 tons Cadmium is applied in agricultural lands in every year in Bangladesh. As continuous application of phosphate fertilizers increase the $\mathrm{Cd}$ concentration in soils and eventually to plants, we need to find out the alternative source of commercial phosphate fertilizers.

\section{References}

Atafar, Z., Mesdaghinia, A., Nouri, J., Homaee, M., Yunesian, M., Ahmadimoghaddam, M. and Mahvi, A.H., 2010.Effect of fertilizer application on soil heavy metal concentration. Environmental monitoring and assessment, 160:1-4.

Alloway, B.J., and Steinnes, E., 1999, Anthropogenic additions of cadmium to soils.In Cadmium in soils and plants , Dordrecht: Springer.

Akter, M., Chowdhury, A.K.,and Chowdhury, M.A.H., 2013, Soil organic matter, mineral nutrients,and heavy metals status of some selected regions of Bangladesh, Journal of Environmental Science and Natural Resources, 5(2): 01-09.

Ali, M.M., Saheed, S.M., Kubota, D., Masunaga, T. and Wakatsuki, T., 1997, Soil degradation during the period 1967-1995 in Bangladesh: I. Carbon and nitrogen, Soil Science and Plant Nutrition, 43 (4): 863878.

Bhuiyan, N.I., 1988. Co-ordinated project on potassium 
studies Progress Report (1987-88), Bangladesh Rice Research Institute, Gazipur, Bangladesh, 1-45.

Black, C.A., 1957, Soil-plant relationships. London, John Wiley And Sons;

Bangladesh Agricultural Research Council (BARC) (2005), Fertilizer recommendation guide.

Cao, H., Chen, J., Zhang, J., Zhang, H., Qiao, L. and Men, Y., 2010, Heavy metals in rice and garden vegetables and their potential health risks to inhabitants in the vicinity of an industrial zone in Jiangsu, China. Journal of environmental sciences, 22(11): 1792-1799.

Cantisano, A., 1997, Know Your Soil-A Handbook for Organic Growers and Gardeners in Temperate and Subtropical Regions.

Debnath, S.K., 2002, Relation and distribution of phosphorus and potassium in soils (Doctoral dissertation, MS Thesis, Department of Soil Science, Bangladesh Agricultural University, Mymensingh).

Dissanayake, C.B.,and Chandrajith, R., 2009, Phosphate mineral fertilizers, trace metals,and human health. Journal of the National Science Foundation of Sri Lanka, 37(3): 153-165.

Fullen, M.A., Jankauskas, B., Jankauskienè, G., Booth, C.A. and Šlepetienè, A., 2007. Inter-relationships between soil texture and soil organic matter content in eroded EutricAlbeluvisols in Lithuania, ZemesUkioMokslai, (3).

Garg, V.K., Yadav, P., Mor, S., Singh, B. and Pulhani, V., 2014, Heavy metals bioconcentration from soil to vegetables and assessment of health risk caused by their ingestion. Biological trace element research, 157(3): 256-265.

Gomes SA, 2005, Study on soil characteristics and species diversity of Madhupur Sal forest. M.S. Thesis, Department of Agroforestry, Bangladesh Agricultural University, Mymensingh, Bangladesh, 21-55.

Huq, S.I. and Alam, M.D., 2005, A handbook on analyses of soil, plant,and water, BACER-DU, University of Dhaka, Bangladesh, 246.

Kabata-Pendias, A. and Pendias, H., 2010. Trace elements in soils and plants, CRC Press, Boca. Raton, FL, USA.

Kim, N., 2008, Cadmium accumulation in Waikato soils, Environment Waikato Regional Council.

Kong, X., Dao, T.H., Qin, J., Qin, H., Li, C. and Zhang, F., 2009. Effects of soil texture and land use interactions on organic carbon in soils in North China cities' urban fringe. Geoderma, 154(1-2):86-92.
Meharg, A.A., Norton, G., Deacon, C., Williams, P., Adomako, E.E., Price, A., Zhu, Y., Li, G., Zhao, F.J., McGrath, S. and Villada, A., 2013, Variation in rice cadmium-related to human exposure, Environmental science \& technology, 47(11),: 5613-5618.

Miah, M.A., Uddin, N., Hoque, M.M., Haq, M.E. and Biswas, A.K., 2017, Physicochemical properties of soil at Habla union ofBasailUpazila in Tangail., Asian Journal of Medical and Biological Research, 2(4): 664-671.

Pennington, J.T. and Calloway, D.H., 1973, Copper content of foods, Factors affecting reported values. Journal of the American Dietetic Association, 63(2): 143-153.

Roberts, A.H.C., Longhurst, R.D. and Brown, M.W., 1994, Cadmium status of soils, plants, and grazing animals in New Zealand. New Zealand Journal of Agricultural Research, 37(1):119-129.

Rabbani, D., Dehghani, R., Gilasi, H. and Abadi, H., 2015, Evaluation of heavy metals in Iranian and NonIranian rice supplied by shopping centers of Kashan, Iran. International archives of health sciences, 2(1): 25-29.

Sharma, R.K., Agrawal, M. and Marshall, F.M., 2008, Heavy metal $(\mathrm{Cu}, \mathrm{Zn}, \mathrm{Cd}$, andPb) contamination of vegetables in urban India: A case study in Varanasi. Environmental Pollution, 154(2): 254-263.

Smith, J.L. and Doran, J.W., 1996, Measurement and use of $\mathrm{pH}$ and electrical conductivity for soil quality analysis, In Methods for assessing soil quality (Vol. 49).Soil Science Society of America Madison, WI.

SRDI, 2001b, Land and Soil Resources Utilization Guide (in Bengali), Upazila Nirdeshika Series-Mymensingh Upazila. Soil Resources Development Institute, Dhaka.

Tirado, R. and Allsop, M. 2012, Phosphorus in agriculture: problems and solutions. Greenpeace Research Laboratories Technical Report (Review), 02-2012.

Wong, S.C.; Li, X.D.; Zhang, G.Q.; Min, Y.S. Heavy metals in agricultural soils of the Pearl River Delta, South China. Environ. Pollute. 2002, 119, 33-44.

Wilson, B.,and Pyatt, F.B., 2007, Heavy metal dispersion, persistence, and bioaccumulation around an ancient copper mine situated in Anglesey, UK, Ecotoxicology and environmental safety, 66(2): 224-231.

Wang, T., Sun, H., Zhang, Y., Jiang, C., Wang, J. and Zhang, Q., 2012, Cadmium immobilization by amendment in polluted farmland in Tianjin, China. Fresenius Environmental Bulletin, 21(11). 